\title{
3D printing applications for the treatment of cancer
}

\author{
Abid Haleem $^{\mathrm{a}}$, Mohd Javaid ${ }^{\mathrm{a}, * *}$, Raju Vaishya ${ }^{\mathrm{b}}$ \\ ${ }^{a}$ Department of Mechanical Engineering, Jamia Millia Islamia, New Delhi, India \\ ${ }^{\mathrm{b}}$ Department of Orthopaedics, Indraprastha Apollo Hospital, Sarita Vihar, Mathura Road, 110076, New Delhi, India
}

A R T I C L E I N F O

\section{Keywords:}

3D printing

Additive manufacturing (AM)

Applications

Cancer

Treatment

Tumour

\begin{abstract}
A B S T R A C T
Purpose: Additive manufacturing (AM) is an innovation in today's medical field. It helps create a patient-specific 3D model of bones, nerves, organs and blood vessel. Now, doctors and surgeons have successfully applied this technology to plan different types of treatments and also cancers. The purpose of this paper is to study the requirements and applications of AM for cancer treatment.

Methods: Today AM is used for the application of regenerative medicine. It can help develop and improve invitro models in the tumour microenvironment. Thus, to identify its applications, related research papers on AM for cancer are studied.

Results: 3D printing technology has a unique capability to manufacture tumour models. It helps to understand the status of the whole tumor. Here in this paper, we studied the capabilities of AM technologies for cancer treatment. This study discusses necessary process steps, followed by 3D printing and finally identified significant applications of these technologies for cancer treatment with a brief description.

Conclusion: 3D printed tumor helps to provide faithful studies on metastasis. These models create a promising platform to construct biomimetic models. By accurate manufacturing of in vitro model, this technology seems to be the best tool to facilitate complex treatment, surgery and therapies. It shows great potential for the printing of organs. This technology is time-saving and avoids time-consuming processes. It has been analysed that AM helps in reducing the duration of treatment of a cancer patient. Researchers are focusing on reducing pain during therapies. They have also tested 3D printed tumor models for different drugs, to eliminate the risks. These models play a significant role in courses of treatments.
\end{abstract}

\section{Introduction}

Globally cancer is being reported as the cause for a large number of human deaths and treatment-related trauma. Additive Manufacturing technologies provide excellent capabilities which offer a better solution for a cancerous tumor. Model printed by this technology help to understand the disease behaviour of a patient. We can construct a 3D object using layer by layer technique. The quality of the object by manipulating the machine parameters and input materials are increased. Additive manufacturing is a useful tool to manufacture patientspecific implants which can further be used successfully for surgical planning. ${ }^{1} \mathrm{AM}$ technologies consist of 3D imaging/scanning, 3D printing and software supports. These technologies can fulfil different challenges and provide several benefits in education, research and patient care. ${ }^{2,3}$ It achieves a higher level of flexibility by using different software and can increase the accuracy and reliability of the process.
This technology thus creates innovation in the medical field.

$\mathrm{AM}$ is used for the development of new tools and equipment in the medical field. This technology is useful for the fabrication of customised maxillo-facial prosthesis implants and another medical device. It provides good collaboration between doctors, radiologists, surgeons and engineers. This technology shortens research and development time of new products. It is a new method of personalised medicine, design and development of implants and medical devices. ${ }^{4,5}$

$3 \mathrm{D}$ printing plays a vital role to enhance the ability of design and development of the product in the medical field. It manufactures customised shape product to fulfil individual patients' requirement. Researchers and medical students can now study fracture/disease in detail without any risk. Its applications are for the planning of complex surgical procedures, training, simulation, diagnosis, and manufacturing of patient-specific implants. ${ }^{6-8}$

$3 \mathrm{D}$ printing is a useful technology to produces accurate prototypes

\footnotetext{
* Corresponding author.

E-mail addresses: ahaleem@jmi.ac.in (A. Haleem), mjavaid@jmi.ac.in (M. Javaid), raju.vaishya@gmail.com (R. Vaishya).

https://scholar.google.co.in/citations? user=4047148AAAAJ\&hl=en (A. Haleem),

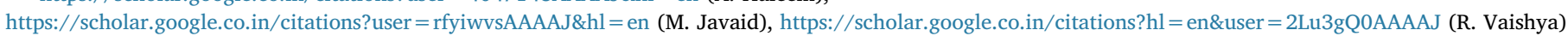


as well as finished parts. This technology can print implants, biocompatible surgical guides with a wide variety of materials. The efficiency of existing products is improved by modification in the design of the product. 3D printing is useful for speeding up the first stages of product development in lesser time and cost. It allows researchers and students to study artefacts in detail without any risk. ${ }^{9-11}$

There are vast applications of 3D printing in the engineering fields. It is readily applicable to make new engineering designs. This technology is used to create cast mould, sub-scale turbine blade mould and various other useful engineering components. Products printed by 3D printing technology are useful for modern engineer's training and help to create an innovative product as per the customer's requirement. ${ }^{12,13}$ This technology is now also applicable in the field of cardiology. This paper describe brief about the capabilities of 3D printing for the treatment of cancer.

\section{Additive Manufacturing}

Additive manufacturing technology sets provide new applications in the treatment of cancer. It consists of different scanning/imaging, 3D printing technologies along with designing, scanning and printing software. The data of the cancer patient is taken quickly by using Computed tomography (CT) and Magnetic Resonance Imaging (MRI) technologies, and further these images are converted into 3D digital computer-aided design (CAD) models by using different software's. This CAD model can be printed quickly by using appropriate 3D printing technology. ${ }^{14,15}$ Here a complex shape is printed (manufactured) layer by layer, and finally, makes a full 3D physical object, and this can be used for treating some types of cancer. 3D printed model of the tumour shows the exact location of this tumour in the patient's body. ${ }^{16}$

Additive manufacturing becomes an important tool for the design and manufacturing of custom parts which can be easily used during the replacement of patients' parts. Its applications are in many fields such as medical, engineering, aerospace, design and manufacturing of prototype before starting the full production. ${ }^{17,18}$ For modification in the design of the existing product, 3D scanners and Imaging machines are now available, which allows creating a digital 3D object from a physical object. 3D Scanner is non-contact scanning technology used to scanned object in the form of point cloud data without any physical contact.

Its applications are in designing of customised orthotic, prosthetic, tools and devices as per the requirement. ${ }^{19}$ It provides a modified concept to the industry as per the desired shape and dimension. 3D scanner increase design quality and efficiency of the final product. AM provides excellent potential for doctors and researchers to create new ideas to understand complex human systems. ${ }^{20,21}$

\section{What is cancer?}

Cells are an essential part of our body which maintains a human body healthy in a controlled manner. Cancer cell starts out of control of the patient by which a tumor creates abnormal cells. Cancer forms a tumor and interferes with body function. It continuously grew and spread through the metastasis process. ${ }^{22}$ Cancer is a large group of disease which rapidly spreads to other organs and tissues. For example, it begins from the lungs and also spreads in the liver. This disease creates an abnormal growth of cells. It forms cells which are not required and cause the growth of a tumor. The primary treatment process of this disease is chemotherapy, surgery, radiation therapy, drug therapy and stem cell transplantation. ${ }^{23}$ For the treatment of cancer, 3D printing offers new dimensions by quickly creating a physical 3D model which precisely shows the patient's tumor. The CAD model of the image can be analysed for better planning of cancer-related treatments and surgery. The significant benefit of this technology is to reduce the risk and improve the treatment outcome. A surgeon can now practice on the procedure to improve the skill using an exact patient-specific 3D model.

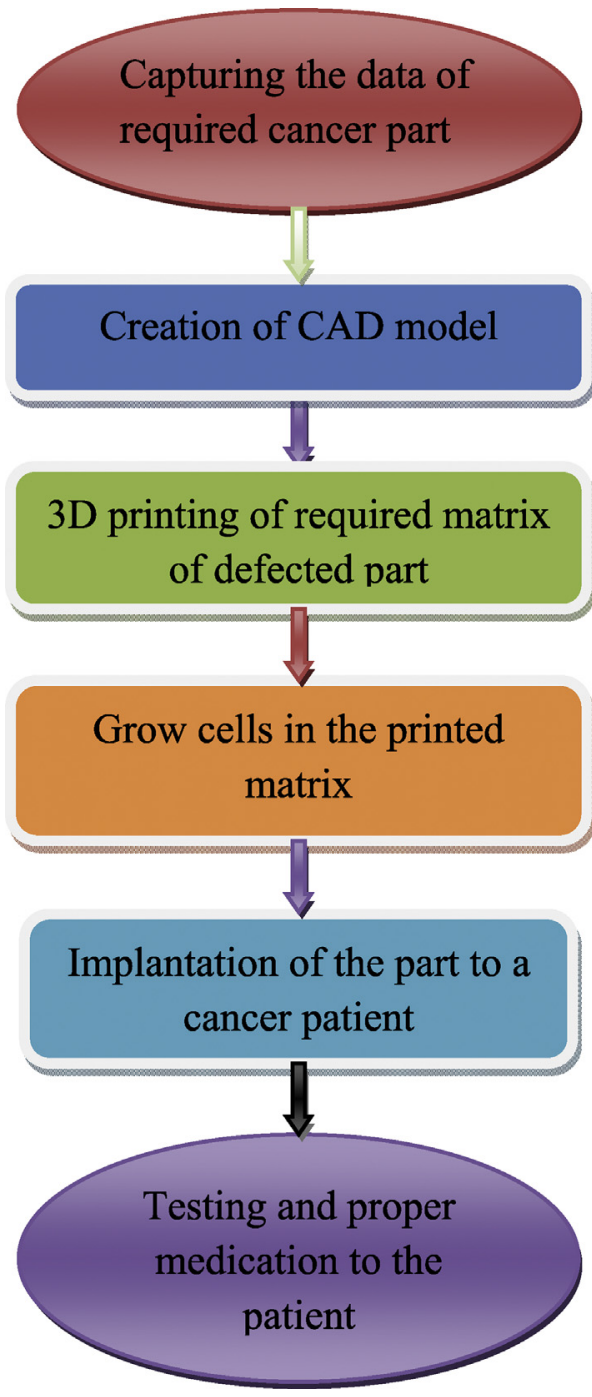

Fig. 1. Process of 3D printing for cancer treatment.

\section{Research objectives}

3D printing already explores its capability for the printing of tissue, organs and cells. Now a day, this technology also helps in the treatment of cancer. It makes safer surgery which can be performed accurately and precisely. The surgeons can easily create a 3D model of the cancerous part and then analyse them before surgery. This patient-specific model is the best approach during the treatment of invasive cancer surgeries. It helps to predict the recovery after performing the surgery. 3D printed model eliminates various risk factors during the surgery. This innovative technology can assist doctors with better planning and treatment. 3D printed patient-specific tumor model make a better treatment decision. This article addresses the following research objectives:

R01: To understand the need for AM and capabilities of AM for cancer treatment;

RO2: to study the process of 3D printing for the treatment of cancer; RO3: to identify significant applications of $3 \mathrm{D}$ printing for cancer treatment;

R04: to study the future scope of this technology regarding the better treatment of cancer. 
Table 1

Some basic applications of 3D printing for cancer treatment.

\begin{tabular}{|c|c|c|c|}
\hline $\begin{array}{l}S \\
\text { No }\end{array}$ & Applications & Description & References \\
\hline 1 & $\begin{array}{l}\text { Accurate replica of the } \\
\text { cancerous part }\end{array}$ & $\begin{array}{l}\text { - Doctors can get precise treatment of cancerous body part of the patient } \\
\text { by creating a personalised replica model } \\
\text { - Help to analyse cancer cells in just a small fraction } \\
\text { - Accurate 3D printed replica helpful to provide better dose to fight Cancer } \\
\text { - 3D printed model is a better option to get precise information as } \\
\text { compared to 2D scan report }\end{array}$ & $\begin{array}{l}\text { Perica and Sun, } 2017^{30} \text {; George et al., } 2017^{31} \text {; Wu et al., } \\
2018^{32}\end{array}$ \\
\hline 2 & Printing of cancerous tumours & $\begin{array}{l}\text { This technology prints cancerous tumours for undertaking research and } \\
\text { development } \\
\text { - } 3 \mathrm{D} \text { printed cancerous tumours provide better ideas as compared to } \\
\text { available 2D/3D imaging } \\
\text { - Having the ability to customise treatment beyond cancer therapies } \\
\text { - Helps surgeon to prepare life-changing surgery } \\
\text { - Successfully used to predict response for different treatment of the } \\
\text { patient }\end{array}$ & Stone, $2014^{33}$; Baek et al.,2016 ${ }^{34}$; Kim et al., $2017^{35}$ \\
\hline 3 & $\begin{array}{l}\text { 3D phantoms of tumours and } \\
\text { organs }\end{array}$ & $\begin{array}{l}\text { - CT/MRI scan data is used to create 3D phantoms of tumours and organs } \\
\text { for better treatment of the patient } \\
\text { - Helps to provide proper dose to kill cancer cells } \\
\text { - Used for the treatment of tumours which spread in the bones } \\
\text { - It enables doctors for personalising treatment and fast recovery of the } \\
\text { patient } \\
\text { - Provide idea for precisely mimic flow inside the tumor } \\
\text { - It is time and cost-effective process to create detail and complex } \\
\text { phantoms }\end{array}$ & $\begin{array}{l}\text { Kijima et al., } 2014^{36} \text {; Hodgdon et al., } 2018^{37} \text {; Haleem et al., } \\
2020^{38}\end{array}$ \\
\hline 4 & Treatment of tumour tissue & $\begin{array}{l}\text { This technology is used for the treatment of tumour tissue and quickly } \\
\text { identifying specific cancer types of disease } \\
\text { - 3D printed patient-specific tumour provides a proper introduction from } \\
\text { different angles } \\
\text { - Perfect 3D printed replica provide accurate shape and size of the tumor } \\
\text { and its surrounding area } \\
\text { - Create innovative advancement in research and clinical cancer } \\
\text { therapeutics }\end{array}$ & Dupret-Bories et al., $2018^{39}$; Lupulescu and Sun, $2019^{40}$ \\
\hline 5 & Accurate geometry of tumour & $\begin{array}{l}\text { - It quickly produces a 3D model of the tumour with precise geometry } \\
\text { which helps for better treatment } \\
\text { - It deposits living cells, layer by layer for the effective treatment of cancer } \\
\text { - This technology used imaging technique for the proper analysis of } \\
\text { tumour }\end{array}$ & Chepelev et al., $2018^{41}$; Fan et al., $2019^{42}$ \\
\hline 6 & Study cancer growth & $\begin{array}{l}\text { - 3D printing model seems helpful to study the process of cancer growth } \\
\text { - Printed models can be used for surgical planning } \\
\text { - 3D printed organ, tissue and tumor provide precise information } \\
\text { regarding the abnormalities } \\
\text { - Helpful to study tumor growth and spread of the cancer }\end{array}$ & Lindegaard et al., $2016^{43}$; Ballard et al.,2018 ${ }^{44}$ \\
\hline 7 & Better teaching tool & $\begin{array}{l}\text { AM technologies are useful in model making, and then these models can } \\
\text { be gainfully used } \\
\text { - Scanning inputs can also be analysed by software, and then simulation } \\
\text { can also be done. } \\
\text { - Provide knowledge about the symptoms of this disease caused by various } \\
\text { reasons } \\
\text { - Accurate ideas about where the tumour is located in the patient body }\end{array}$ & $\begin{array}{l}\text { Libby and Silberstein, } 2017^{45} \text {; Garcia et al., } 2018^{46} \\
\text { Javaid and Haleem, } 2019^{47} \text {; Haleem and Javaid, } 2019^{48}\end{array}$ \\
\hline 8 & $\begin{array}{l}\text { Monitoring of cancer } \\
\text { treatment }\end{array}$ & $\begin{array}{l}\text { - Help to monitor different stages by using support software when } \\
\text { provided with scan data } \\
\text { - It makes easier treatment by identifying the stages of diseases } \\
\text { - Different biocompatible materials printed by this technology can increase } \\
\text { patient care }\end{array}$ & $\begin{array}{l}\text { Westerman et al., } 2016^{49} \text {; Santiago et al. } 2019^{22} \text {; Javaid } \\
\text { et al., } 2019^{50} \text {; Kim et al., } 2019^{16}\end{array}$ \\
\hline 9 & Skin cancer treatment & $\begin{array}{l}\text { - 3D printing address optimum planning of radiation and normal anatomy } \\
\text { of the tumor } \\
\text { - It enables radiation for the treatment of skin cancer and superficial tissue } \\
\text { - This technology creates a reality of handheld models }\end{array}$ & Priester et al., $2014^{51}$; Witowski et al., $2017^{52}$ \\
\hline
\end{tabular}

\section{Need for Additive Manufacturing for cancer treatment}

Treatment of cancer is quite challenging and is undertaken through different types of therapies. 3D printing is part of AM used for printing CAD file of the tumor. Tumour imagining is analysed through AM software can be used to analyse the mechanism of various physiological aspects in a patient. This technology prints tumor model for a better understanding of patient and doctors. By using this technology, there is a possibility to collect information regarding the cells of a tumour. ${ }^{24}$ In the medical field, this technology can focus on reducing pain during cancer treatment. It can be thought of using long-lasting cancer treatments, like radiation therapy and chemotherapy. It is applied successfully for breast cancer. ${ }^{25,26}$ In this process tumour, cells are taken and print tumour. Thus, further helps to different tryout drugs and sort out the best treatment for the patient. ${ }^{27}$

\section{Process of 3D printing for cancer treatment}

3D printing manufactures a physical part, directly from a 3D CAD file, when provided in Standard Triangulate Language (STL) format. It creates a part layer by layer, which is opposed to subtractive manufacturing technologies. 3D printing is direct manufacturing of finished product without any requirement of tools and fixture. It plays a vital role in product development. ${ }^{28,29}$ This technology reduces the cost of 
product development and cycle time. It is easy to use and create an ecofriendly cost-effective product. Fig. 1 shows the process of 3D printing for cancer treatment.

The first step is to capture the required data of the patient using different scanning and imaging technologies. This data is converted into a CAD 3D model using different software and further, convert it into the required printable format. After the conversion of data, this data is used in $3 \mathrm{D}$ printing technology for the printing of the required matrix of the defected part of a cancer patient. Finally, this part is implanted in the patient body, or it is also used for testing and to provide proper medication to the patient.

\section{3D printing applications for cancer treatment}

AM software helps to simulate several medical procedures by producing and analysing the required specified CAD models, further, they can be printed. Tumor model manufactured by this technology provides accurate behaviour of the patient body. Doctors can surgeon can analyse the tumor and take its advantage for better treatment. Table 1 discusses the different applications of 3D printing for cancer treatment.

The applications of this technology are extensive, starting from imaging to software modelling. It can create a 3D model from image files, which can be helpful to show the detailed flow of radiopharmaceuticals in the patient's body. Thus, it helps for the treatment of other tumours like cancers of nerves cells in children, thyroid cancer and bone tumour. Effective communication is required in today's medical field. ${ }^{53-56}$ This technology is right to plan a reconstructive surgery by manufacturing accurate implant with different materials. This technology is now used for the printing of tissues, organs and stem cell printing. With the input of biocompatible material, a scaffold is efficiently manufactured by which cells and tissue can grow and creates their shape. It is a useful technique to build a 3D hollow vessel structure.

\section{Discussion}

Millions of deaths are reported due to the cause of cancer. 3D printing is an innovative technology used to construct the 3D model layer by layer, which is helpful for the treatment of cancer patient. This technology uses different types of materials as well as a natural material with living cells/tissue. ${ }^{57-59}$ It used a combination of biomaterials, bioactive additives or cells. 3D models are used for tumor biology, which includes 3D cell migration, cell proliferation, nutrient etc. It is an emerging method for the manufacturing of scaffold, which is helpful to grow living tissue. It has the capability to build a complex and heterogeneous structure which was not easily possible with traditional technique. This technology investigates cellular physiology in a controlled manner. Doctors can now print entire prosthetic limbs with an accurate patient match. Today 3D printing is used to print models of tissues with blood vessels, prosthetic parts, bones, cardiovascular models, heart valves, ear cartilage, and synthetic skin. These printed models provide proper information on cancer tumours. ${ }^{60-62}$ It showed the status of growing tumours for the individual treatment of the patient with the use of AM. This technology is used for the treatment of kidney cancer. It quickly develops tissue therapeutics, which is helpful for regenerative medicine and therapeutic discovery.

\section{Future scope}

In future, applications with AM technologies will provide towards the effective and precise treatment of cancer patient. This technology has great potential to fulfil the shortage of donor. It overcomes the challenge of whole organ replacement by creating a functional one. 3D printing accelerates the development of cancer immunotherapy. Doctors are accelerating the 3D printing impact to increase cancer patient care. In future, this technology can be applied to manufacture in vitro models of metastasis. It produces effective results for tissue engineering. In upcoming days, it will become a perfect tool to create human arms, hands and legs which will work as a normal. With its reconstruction ability, it can save millions of lives. It will enable to print human skin which can be helpful for the treatment of skin cancer.

\section{Conclusion}

3D printed tumour models can easily convey inside information of a patient's body. It is used for developing personalised anti-cancer drugs. The main challenge of this technology is to create an effective treatment of cancer. Scientist and researcher analysed the development of tumour mesh by using an accurate model printed by this technology. 3D printed model also helps for the better diagnosis of cancer treatment. This technology has emerged for the treatment of liver-related surgeries. It is helpful to check the status/condition of liver disease. The 3D printed tumor has the ability to analyse the tumor and provide the proper drug for the patient. These proper drugs help to bind cancer cell for better treatment of the patient. It addresses cancer with the help of personalised treatment modality.3D printed surgical guides are helpful for the cancer patient while undergoing chemotherapy. 3D printed medical tools and devices are helpful for precisely removing the tumor. It has excellent capability to create complex \& customised 3D cell biology. In future, 3D printing will be applied to provide proper dose to kill cancer cell without damaging the healthy tissues.

\section{Declaration of competing interest}

None.

\section{References}

1. Javaid M, Haleem A. Additive manufacturing applications in orthopaedics: a review. J Clin Orthop Trauma. 2018;9(3):202-206.

2. Ciocca L, Scotti R. Oculo-facial rehabilitation after facial cancer removal: updated CAD/CAM procedures: a pilot study. Prosthet Orthot Int. 2014;38(6):505-509.

3. Hong D, Lee S, Kim T, et al. Usefulness of a 3D-printed thyroid cancer phantom for clinician to patient communication. World J Surg. 2019. https://doi.org/10.1007/ s00268-019-05260-z.

4. Giannopoulos AA, Steigner ML, George E, et al. Cardiothoracic applications of 3dimensional printing. J Thorac Imag. 2016;31(5):253-272.

5. Alyaev YG, Sirota ES, Bezrukov EA, et al. Application of 3D soft print models of the kidney for treatment of patients with localised cancer of the kidney (a pilot study). Urologiia. 2017;6:12-19.

6. Javaid M, Haleem A. 3D printing applications towards the required challenge of stem cells printing. Clin Epidemiol Global Health. 2020. https://doi.org/10.1016/j.cegh. 2020.02 .014$.

7. Wake N, Rude T, Kang SK, et al. 3D printed renal cancer models derived from MRI data: application in pre-surgical planning. Abdom Radiol (NY). 2017;42:1501-1509.

8. Ho BHK, Chen CJ, Tan GJS, et al. Multi-material three dimensional printed models for simulation of bronchoscopy. BMC Med Educ. 2019;19(1):236. https://doi.org/10. 1186/s12909-019-1677-9.

9. Mitsouras D, Liacouras P, Imanzadeh A, et al. Medical 3D printing for the radiologist. Radiographics. 2015;35(7):1965-1988.

10. Wake N, Rosenkrantz AB, Huang R, et al. Patient-specific 3D printed and augmented reality kidney and prostate cancer models: impact on patient education. 3D Print Med. 2019;5:4-9.

11. Javaid M, Haleem A. Current status and applications of additive manufacturing in dentistry: a literature-based review. J Oral Biol Craniofac Res. 2019;9:179-185.

12. Chadha A, UlHaq M, Raina A, Singh R, Penumarti N, Bishnoi M. Effect of fused deposition modelling process parameters on mechanical properties of 3D printed parts. World J Eng. 2019. https://doi.org/10.1108/WJE-09-2018-0329.

13. Javaid M, Haleem A. 3D printed tissue and organ using additive manufacturing: an overview. Clin Epidemiol Global Health. 2019. https://doi.org/10.1016/j.cegh.2019. 12.008 .

14. Chae MP, Hunter-Smith DJ, Spychal RT, Rozen WM. 3D volumetric analysis for planning breast reconstructive surgery. Breast Canc Res Treat. 2014;146(2):457-460

15. Haleem A, Javaid M. Role of CT and MRI in the design and development of orthopaedic model using additive manufacturing. J Clin Orthop Trauma. 2018;9(3):213-217.

16. Kim MJ, Chi BH, Yoo JJ, Ju YM, Whang YM, Chang IH. Structure establishment of three-dimensional (3D) cell culture printing model for bladder cancer. PloS One. 2019;14(10):e0223689https://doi.org/10.1371/journal.pone.0223689.

17. Haleem A, Javaid M. Polyether ether ketone (PEEK) and its 3D printed implants applications in the medical field: an overview. Clin Epidemiol Global Health. 
2019;7(4):571-577

18. Chia HN, Wu BM. Recent advances in 3D printing of biomaterials. $J$ Biol Eng. 2015;9:4. https://doi.org/10.1186/s13036-015-0001-4.

19. Haleem A, Javaid M. 3D scanning applications in medical field: a literature-based review. Clin Epidemiol Global Health. 2019;7(2):199-210.

20. Huang X, Liu Z, Wang X, et al. A small 3D-printing model of macroadenomas for endoscopic endonasal surgery. Pituitary. 2019;22(1):46-53.

21. Javaid M, Haleem A. Additive manufacturing applications in medical cases: a literature-based review. Alexandria J Med. 2018;54(4):411-422.

22. Santiago L, Adrada BE, Caudle AS, Clemens MW, Black DM, Arribas EM. The role of three-dimensional printing in the surgical management of breast cancer. J Surg Oncol. 2019;120(6):897-902.

23. Park SY, Choi CH, Park JM, Chun M, Han JH, Kim JI. A patient-specific Polylactic acid bolus made by a 3D printer for breast Cancer radiation therapy. PloS One. 2016;11(12):e0168063https://doi.org/10.1371/journal.pone.0168063.

24. Albritton JL, Miller JS. 3D bioprinting: improving in vitro models of metastasis with heterogeneous tumor microenvironments. Dis Model Mech. 2017;10(1):3-14.

25. Javaid M, Haleem A. 3D printed medical parts with different materials using additive manufacturing. Clin Epidemiol Global Health. 2019. https://doi.org/10.1016/j.cegh. 2019.08.002.

26. Roberts S, Peyman S, Speirs V. Current and emerging 3D models to study breast cancer. Adv Exp Med Biol. 2019;1152:413-427.

27. Yao R, Xu G, Mao SS, et al. Three-dimensional printing: review of application in medicine and hepatic surgery. Cancer Biol Med. 2016;13:443-451.

28. Javaid M, Haleem A. Current status and challenges of Additive manufacturing in orthopaedics: an overview. J Clin Orthop Trauma. 2019;10(2):380-386.

29. Javaid M, Haleem A. Industry 4.0 applications in medical field: a brief review. Curr Med Res Pract. 2019;9(3):102-109.

30. Perica E, Sun Z. Patient-specific three-dimensional printing for pre-surgical planning in hepatocellular carcinoma treatment. Quant Imag Med Surg. 2017;7(6):668-677.

31. George E, Liacouras P, Rybicki FJ, Mitsouras D. Measuring and establishing the accuracy and reproducibility of 3D printed medical models. Radiographics. 2017;37(5):1424-1450.

32. Wu Y, Chen N, Xu Z, et al. Application of 3D printing technology to thoracic wall tumor resection and thoracic wall reconstruction. $J$ Thorac Dis. 2018;10(12):6880-6890.

33. Stone L. Kidney cancer: a model for the masses-3D printing of kidney tumours. Nat Rev Urol. 2014;11:428. https://doi.org/10.1038/nrurol.2014.167.

34. Baek MH, Kim DY, Kim N, Rhim CC, Kim JH, Nam JH. Incorporating a 3-dimensional printer into the management of early-stage cervical cancer. J Surg Oncol, 2016;114:150-152.

35. Kim MJ, Lee SR, Lee MY, et al. Characterisation of 3D printing techniques: toward patient-specific quality assurance spine-shaped phantom for stereotactic body radiation therapy. PloS One. 2017;12(5):e0176227https://doi.org/10.1371/journal. pone.0176227.

36. Kijima S, Sasaki T, Nagata K, Utano K, Lefor AT, Sugimoto H. Preoperative evaluation of colorectal cancer using CT colonography, MRI, and PET/CT. World J Gastroenterol. 2014;7(20):16964-16975.

37. Hodgdon T, Danrad R, Patel MJ, et al. Logistics of three-dimensional printing: primer for radiologists. Acad Radiol. 2018;25(1):40-51.

38. Haleem A, Javaid M, Khan RH, Suman R. 3D printing applications in bone tissue engineering. $J$ Clin Orthop Trauma. 2020;11:118-124.

39. Dupret-Bories A, Vergez S, Meresse T, et al. Contribution of 3D printing to mandibular reconstruction after cancer. Eur Ann Otorhinolaryngol Head Neck Dis. 2018;135:133-136.

40. Lupulescu C, Sun Z. A systematic review of the clinical value and applications of three-dimensional printing in renal surgery. J Clin Med. 2019;8(7):990. https://doi. org $/ 10.3390 /$ jcm8070990.

41. Chepelev L, Wake N, Ryan J, et al. Radiological Society of North America (RSNA) 3D printing Special Interest Group (SIG): guidelines for medical 3D printing and appropriateness for clinical scenarios. 3D Print Med. 2018;4(1):11. https://doi.org/10. 1186/s41205-018-0030-y.

42. Fan G, Meng Y, Zhu S, et al. Three-dimensional printing for laparoscopic partial nephrectomy in patients with renal tumors. J Int Med Res. 2019;47(9):4324-4332.

43. Lindegaard JC, Madsen ML, Traberg A, et al. Individualised 3D printed vaginal template for MRI guided brachytherapy in locally advanced cervical cancer. Radiother Oncol: journal of the European Society for Therapeutic Radiology and Oncology. 2016;118(1):173-175

44. Ballard DH, Trace AP, Ali S, et al. Clinical applications of 3D printing: primer for radiologists. Acad Radiol. 2018;25(1):52-65

45. Libby RS, Silberstein JL. Physical model of clear-cell renal carcinoma with inferior vena cava extension created from a 3-dimensional printer to aid in surgical resection: a case report. Clin Genitourin Canc. 2017;15:867-869.

46. Garcia J, Yang Z, Mongrain R, Leask RL, Lachapelle K. 3D printing materials and their use in medical education: a review of current technology and trends for the future. BMJ Simul Technol Enhanc Learn. 2018;4(1):27-40.

47. Javaid M, Haleem A. 4D printing applications in medical field: a brief review. Clin Epidemiol Global Health. 2019;7(3):317-321.

48. Haleem A, Javaid M. Polyether ether ketone (PEEK) and its manufacturing of customised 3D printed dentistry parts using additive manufacturing. Clin Epidemiol Global Health. 2019. https://doi.org/10.1016/j.cegh.2019.03.001.

49. Westerman ME, Matsumoto JM, Morris JM, Leibovich BC. Three-dimensional printing for renal cancer and surgical planning. Eur Urol Focus. 2016;2:574-576.

50. Javaid M, Haleem A, Kumar L. Current status and applications of 3D scanning in dentistry. Clin Epidemiol Global Health. 2019;7(2):179-185.

51. Priester A, Natarajan S, Le JD, et al. A system for evaluating magnetic resonance imaging of prostate cancer using patient-specific 3D printed molds. Am J Clin Exp Urol. 2014;2:127-135.

52. Witowski JS, Pędziwiatr M, Major P, Budzyński A. Cost-effective, personalised, 3Dprinted liver model for preoperative planning before laparoscopic liver hemihepatectomy for colorectal cancer metastases. Int J Comput Assist Radiol Surg. 2017;12:2047-2054.

53. Haleem A, Javaid M. Enablers, barriers and critical success factors for effective adoption of colour-jet 3D printing technology. J Ind Integrat Manag. 2019. https:// doi.org/10.1142/S242486221950009X.

54. Aziz R, Haq MI, Raina A. Effect of surface texturing on friction behaviour of 3D printed polylactic acid (PLA). Polym Test. 2020. https://doi.org/10.1016/j. polymertesting.2020.106434.

55. Awasthi S, Verma T, Agarwal M, Singh JV, Srivastava NM, Nichterd M. Developing effective health communication messages for community-acquired pneumonia in children under five years of age: a rural North Indian qualitative study. Clin Epidemiol Global Health. 2017;5:107-116.

56. Chae MP, Rozen WM, McMenamin PG, Findlay MW, Spychal RT, Hunter-Smith DJ. Emerging applications of bedside 3D printing in plastic surgery. Front Surg. 2015;2:25. https://doi.org/10.3389/fsurg.2015.00025.

57. Lambert A, Valiulis S, Cheng Q. Advances in optical sensing and bioanalysis enabled by 3D printing. ACS Sens. 2018;3(12):2475-2491.

58. Wendler JJ, Klink F, Seifert S, et al. Irreversible electroporation of prostate Cancer: patient-specific pretreatment simulation by electric field measurement in a 3D bioprinted textured prostate Cancer model to achieve optimal electroporation parameters for image-guided focal ablation. Cardiovasc Intervent Radiol. 2016;39:1668-1671.

59. Schulz-Wendtland R, Harz M, Meier-Meitinger M, et al. Semi-automated delineation of breast cancer tumors and subsequent materialisation using three-dimensional printing (rapid prototyping). J Surg Oncol. 2017;115(3):238-242.

60. Knowlton S, Onal S, Yu CH, Zhao JJ, Tasoglu S. Bioprinting for cancer research. Trends Biotechnol. 2015;33(9):504-513.

61. Zhu W, Holmes B, Glazer RI, Zhang LG. 3D printed nanocomposite matrix for the study of breast cancer bone metastasis. Nanomed Nanotechnol Biol Med. 2016;12(1):69-79.

62. Serrano DR, Terres MC, Lalatsa A. Applications of 3D printing in cancer. J 3D printing Med. 2018;2(3):115-127. 